\title{
The regulation of ciliary beat frequency by ovarian steroids in the guinea pig Fallopian tube: interactions between oestradiol and progesterone
}

\author{
Takashi Nakahari ${ }^{1,2}$, Ayumi Nishimura ${ }^{1,2}$, Chikao Shimamoto ${ }^{1,3}$, Akiko Sakai ${ }^{1,6}$, Hiroko Kuwabara ${ }^{1,4}$, \\ Takashi Nakano ${ }^{1,5}$, Saori TanaKa ${ }^{1,7}$, Yuka Kohdi ${ }^{1,7}$, Hitoshi Matsumura ${ }^{1,7}$, and Hiroshi Mori ${ }^{1,4}$ \\ ${ }^{1}$ Nakahari Project of Central Research Laboratory, and ${ }^{2}$ Departments of Physiology, ${ }^{3}$ Medical Education, ${ }^{4}$ Pathology, ${ }^{5}$ Microbiology \\ and Infection Control, ${ }^{6}$ Chemistry, Osaka Medical College, 2-7 Daigaku-cho, Takatsuki 569-8686, Japan, and ${ }^{7}$ Laboratory of Pharma- \\ cotherapy, Osaka University of Pharmaceutical Sciences, Takatsuki 569-1094, Japan
}

(Received 11 May 2011; and accepted 29 July 2011)

\begin{abstract}
Ciliary beat frequency (CBF) was measured in slice preparations of the Fallopian tube fimbria, using videomicroscopy with a high-speed $(500 \mathrm{~Hz})$ camera in guinea pigs that were treated with $\beta$-oestradiol benzoate $\left(\beta \mathrm{E}_{2} \mathrm{~B}\right)$ and medroxy progesterone (mPRG). In non-ovulating guinea pigs at 4 weeks of age, the CBF of the fimbria was high $(17.8 \mathrm{~Hz})$. In sexually mature guinea pigs $(12-$ 16 weeks of age) with constant ovulation, the CBF varied from $12 \mathrm{~Hz}$ to $16 \mathrm{~Hz}$. The in vivo administration of both ICI-182,780 (a blocker of $\beta \mathrm{E}_{2}$ receptors) and mifepristone (a blocker of PRG receptors) induced high $\mathrm{CBF}(17.4 \mathrm{~Hz})$. The administration of $\beta \mathrm{E}_{2} \mathrm{~B}$ at a low $(3.2 \mathrm{mg} / \mathrm{kg} / \mathrm{day})$ or high $(32 \mathrm{mg} / \mathrm{kg} /$ day $)$ dose decreased the CBF to $14.5 \mathrm{~Hz}$ or $11 \mathrm{~Hz}$, respectively. ICI-182,780 abolished the $\beta \mathrm{E}_{2} \mathrm{~B}$-induced changes in $\mathrm{CBF}$ and decreased $\mathrm{CBF}$ to $12 \mathrm{~Hz}$. The administration of $\mathrm{mPRG}(6.4 \mathrm{mg} / \mathrm{kg} /$ day) decreased CBF to $12.5 \mathrm{~Hz}$. Mifepristone abolished this mPRG-induced decrease in $\mathrm{CBF}$ and maintained the $\mathrm{CBF}$ at $15 \mathrm{~Hz}$. However, administering both $\beta \mathrm{E}_{2} \mathrm{~B}$ and $\mathrm{mPRG}$ increased $\mathrm{CBF}$ to $17.5 \mathrm{~Hz}$, suggesting that $\beta \mathrm{E}_{2} \mathrm{~B}$ inhibits $\mathrm{mPRG}$ actions and vice versa. To confirm the interactions between $\beta \mathrm{E}_{2} \mathrm{~B}$ and $\mathrm{mPRG}$, we administered both $\beta \mathrm{E}_{2} \mathrm{~B}$ and $\mathrm{mPRG}$ to guinea pigs that were pretreated for 1.5 days with either $\mathrm{mPRG}(6.4 \mathrm{mg} / \mathrm{kg} /$ day $)$ or $\beta \mathrm{E}_{2} \mathrm{~B}(3.2 \mathrm{mg} / \mathrm{kg} / \mathrm{day})$. Prior treatment with $\beta \mathrm{E}_{2} \mathrm{~B}$ or $\mathrm{mPRG}$ prevented the increase in $\mathrm{CBF}$ that was otherwise by $\beta \mathrm{E}_{2} \mathrm{~B}$ plus $\mathrm{mPRG}$, and maintained the CBF at $14.5 \mathrm{~Hz}$ or $13 \mathrm{~Hz}$, respectively. The administration of $\beta \mathrm{E}_{2} \mathrm{~B}$ plus $\mathrm{mPRG}$ still induced the expression of PRG receptors, indicating that the highest CBF is not the result of no expression of the receptors. In the beating cilia of the fimbria, the signals that are activated by the $\beta E_{2}$ and $P R G$ receptors are proposed to antagonize each other in regulating the frequency.
\end{abstract}

Female patients with primary ciliary dyskinesia and immotile endometrial cilia were infertile. Therefore, immotile cilia have been suggested to be incapable of transporting the egg along the Fallopian tube. A later study showed that fertility is low in women with immotile cilia syndrome (1). Talbot et al. (1999)

Address correspondence to: Takashi Nakahari, MD Department of Physiology, Osaka Medical College, Takatsuki 569-8686, Japan Tel: +81-72-684-6420, Fax: +81-72-684-6520

E-mail: takan@art.osaka-med.ac.jp demonstrated that the beating cilia on the outer surface of the infundibulum cause the transport of oocyte into the ostium of the Fallopian tube (23). Thus, the beating cilia in the Fallopian tube play an important role in gamete transport.

The ciliary beat frequency (CBF) of the ciliary cells (in the fimbrial region of the Fallopian tube) undergoes cyclic fluctuations that depend on the stages of the ovarian cycle. These cyclic changes in $\mathrm{CBF}$ are controlled by the concentrations of $\beta$-oestradiol $\left(\beta \mathrm{E}_{2}\right)$ and progesterone (PRG), both of which fluctuate throughout the ovarian cycle (15). A 
characteristic CBF corresponding to each phase in the ovarian cycle can be mimicked by the in vivo administration of $\beta \mathrm{E}_{2}$ benzoate $\left(\beta \mathrm{E}_{2} \mathrm{~B}\right)$ or medroxyPRG (mPRG) (15). A previous report showed that the in vitro addition of PRG decreased $\mathrm{CBF}$ in a human Fallopian tube explant (fimbrial region) by 40 $50 \%$ (13). Moreover, both $\beta \mathrm{E}_{2}$ and $\mathrm{PRG}$ receptors have been found in the epithelia of the Fallopian tubes, and the expressions of these two receptors vary in relation to the phase of the ovarian cycle (3, $16,18,24)$. These observations indicate that $\mathrm{CBF}$ in the fimbria is regulated by $\beta E_{2}$ and $P R G$.

On the other hand, $\beta \mathrm{E}_{2}$ has been demonstrated to prevent PRG-induced decreases in CBF (13). Moreover, the effects of endogenous PRG were not detected in guinea pigs that were treated with a high dose of $\beta \mathrm{E}_{2} \mathrm{~B}$ (15). These results suggest that $\beta \mathrm{E}_{2}$ antagonizes the effects of $P R G$ on $\mathrm{CBF}$ in the fimbria. Some reports have shown that PRG signaling antagonizes or interacts with $\beta \mathrm{E}_{2}$ signaling. For example, the $\beta \mathrm{E}_{2}$-induced retraction of long primary dendrites in the ventrolateral ventromedial nucleus of the hypothalamus was reversed with PRG treatment (6). PRG antagonized the ability of $\beta \mathrm{E}_{2}$ to confer neuroprotection against $\mathrm{N}$-methyl-D-aspartate toxicity (2), PRG partially antagonized $\beta \mathrm{E}_{2}$ signaling in the growth of breast cancer cells (20), and $\beta \mathrm{E}_{2}$ and $\mathrm{PRG}$ interacted in glucose homeostasis in diabetic rats (9). These observations may suggest that $\mathrm{PRG}$ and $\beta \mathrm{E}_{2}$ also interact in regulating $\mathrm{CBF}$ in the fimbria.

A light microscope that was connected to a highspeed $(500 \mathrm{~Hz})$ camera enabled us to directly observe the beating cilia of the epithelial surface, as was previously reported in the trachea, bronchiole, and brain ventricle $(5,14,21,22)$. This method allows one to measure the CBF in the fimbria (15). In the present study, we hypothesized that $\beta \mathrm{E}_{2}$ antagonizes the actions of PRG and vice versa, to regulate $\mathrm{CBF}$ in the fimbria. To test this hypothesis, we performed in vivo experiments, in which the $\mathrm{CBF}$ was measured in the fimbria of guinea pigs that were treated with $\beta \mathrm{E}_{2} \mathrm{~B}$ and $\mathrm{mPRG}$.

\section{MATERIALS AND METHODS}

Solution and chemicals. The control solution contained: $121 \mathrm{mM} \mathrm{NaCl}, 4.5 \mathrm{mM} \mathrm{KCl}, 1 \mathrm{mM} \mathrm{MgCl}_{2}$, $1.5 \mathrm{mM} \mathrm{CaCl} 2,25 \mathrm{mM} \mathrm{NaHCO}, 5 \mathrm{mM}$ NaHEPES, $5 \mathrm{mM}$ HHEPES, and $5 \mathrm{mM}$ glucose. The $\mathrm{pH}$ of the solutions was adjusted to 7.4 by the addition of $1 \mathrm{M}$ $\mathrm{HCl}$. The solution was aerated with a gas mixture $\left(95 \% \mathrm{O}_{2}\right.$ and $\left.5 \% \mathrm{CO}_{2}\right)$. All of the experiments were performed at $37^{\circ} \mathrm{C}$. $\beta$-oestradiol benzoate $\left(\beta \mathrm{E}_{2} \mathrm{~B}\right)$, medroxy progesterone (mPRG), and mifepristone (a progesterone receptor blocker) were purchased from Wako Pure Chemicals (Tokyo, Japan) and ICI-182,780 (a $\beta \mathrm{E}_{2}$ receptor blocker) was purchased from Tocris Bioscience (Ellisville, MI63021, USA). These drugs were suspended in a modified phosphate-buffered solution (PBS) that contained 0.4\% polysorbate- $80,0.5 \%$ carboxymethyl cellulose, and $0.5 \%$ benzyl alcohol in PBS $(15,19)$. The anti-oestrogen receptor $\alpha$ antibody (sc-543, Santa Cruz) and anti-progesterone receptor antibody (sc-539, Santa Cruz) were used for western blot analysis.

Animals and treatments. Female guinea pigs (SLC Inc., Hamamatsu, Japan) were purchased at 8 weeks of age and fed a standard pellet diet and water until 12-16 weeks of age. In guinea pigs, the ovulation begins at 8 weeks of age, and after 12 weeks of age, ovulation occurs cyclically (the cycle is 16-21 days). The guinea pigs (weighing 500-700 g) were anesthetized with an intraperitoneal injection of pentobarbital sodium (Nembutal $60-70 \mathrm{mg} / \mathrm{kg}$ ). Under anaesthesia, blood was collected from the heart by a heparinized syringe and the animals were sacrificed. Then, both ovaries including the fimbriae were removed from the animals and the fimbriae were isolated from the ovaries. The fimbriae were washed and stored in the control solution at $4^{\circ} \mathrm{C}$ until $\mathrm{CBF}$ measurement. The blood was centrifuged for $10 \mathrm{~min}$ at $4000 \mathrm{rpm}(3000 \times g)$ to separate the cells from the plasma. After centrifugation, the plasma was collected and stored at $-20^{\circ} \mathrm{C}$ until the hormone assay was performed. The $\beta \mathrm{E}_{2}$ and $\mathrm{PRG}$ concentrations in the samples were measured using an oestradiol-EIA kit (No. 582251; Cayman, Ann Arbor MI 48108, USA) or progesterone EIA kit (No. 582601; Cayman), respectively.

To examine the effects of $\beta E_{2}$ and $P R G$ on CBF, $\beta \mathrm{E}_{2} \mathrm{~B}$ or mPRG (suspended in the modified PBS) was subcutaneously injected three times over 1.5 days (15). The doses of the drugs were calculated based on body weight. The drugs were injected at 8 $\mathrm{pm}$ on the first day and at $9 \mathrm{am}$ and $8 \mathrm{pm}$ on the second day, and then the animals were sacrificed at $9 \mathrm{am}$ on the third day. A series of experiments, such as an injection with $3.2 \mathrm{mg} / \mathrm{kg} /$ day of $\beta \mathrm{E}_{2} \mathrm{~B}$, were performed at intervals of at least 3 or 4 days using 3-4 animals. Without any drug administration, the CBF measured at 3-4 day intervals can vary due to the changes in the concentrations of $\beta \mathrm{E}_{2}$ and $\mathrm{PRG}$ that are endogenously secreted at various phases during the ovarian cycle (15). However, injecting 
ovarian steroids renders the CBF constant. The procedures and protocols for these experiments were performed in accordance with the guidelines of the Animal Research Committee of Osaka Medical College and the Guiding Principles for the care and use of animals in the field of physiological sciences (Physiological Society of Japan).

Measurement of $C B F$. The isolated fimbriae were cut into small pieces $(0.5-1 \mathrm{~mm}$ blocks $)$ that were placed in a micro-perfusion chamber $(30 \mu \mathrm{L})$. The chamber containing the tissue blocks was mounted on the heated stage $\left(37^{\circ} \mathrm{C}\right)$ of an inverted light microscope (T2000; Nikon, Tokyo) that is connected to a high-speed camera (FASTCAM-512PCI; Photoron Ltd., Tokyo). The samples were perfused with the control solution (at $37^{\circ} \mathrm{C}$ ) aerated with $95 \% \mathrm{O}_{2}$ and $5 \% \mathrm{CO}_{2}$ at a perfusion rate of $300 \mu \mathrm{L} / \mathrm{min}$. For measuring $\mathrm{CBF}$, video images were recorded at $500 \mathrm{~Hz}$ for $2 \mathrm{~s}$. In both fimbriae from a given animal, the video images were sampled at 25-30 spots. The CBF was measured using a program for image analysis (DIPP-Motion 2D; DITECT, Tokyo). In a spot image, 10 cells were selected and their CBFs were measured. CBF was measured in $250-300$ cells from each animal, and the average CBF was considered as the CBF for that animal. The isolated fimbriae were used for experiments within $3 \mathrm{~h}$.

The statistical significance of the differences between the means was assessed using a paired or unpaired Student's $t$-test or an ANOVA, as appropriate. Differences were considered significant at $P<0.05$.

Western blot analysis. The frozen isolated fimbriae were homogenized in RIPA buffer ( $\mathrm{pH}$ 7.4) that contained $50 \mathrm{mM}$ Tris- $\mathrm{HCl}, 150 \mathrm{mM} \mathrm{NaCl}, 1 \% \mathrm{NP}-40$, $0.1 \%$ Na-dodecyl sulfate, $0.25 \% \mathrm{Na}$-deoxycholate, and protease inhibitor cocktail (Sigma). The homogenate was incubated on ice for $60 \mathrm{~min}$ and then centrifuged $(15000 \times g)$ for $30 \mathrm{~min}$ at $4^{\circ} \mathrm{C}$. The protein concentration in the supernatant was determined using a protein assay kit (Bio-Rad, Hercules, CA, USA), and the proteins $(20 \mu \mathrm{g})$ were separated by SDS-PAGE on a $7.5 \%$ gel, followed by semi-dry transfer to a polyvinylidene fluoride membrane (Millipore Co., Billerica, MA, USA). The membrane was incubated with an anti-oestrogen receptor $\alpha(E R \alpha)$ or anti-progesterone (PR) antibody and 3\% non-fat dry milk (GE Healthcare, Fairfield, CT, USA) in Tris-buffered saline containing $0.1 \%$ Tween-20 or Can Get Signal Immunoreaction Enhancer solution (Toyobo Co., Osaka, Japan). The protein bands were visualized using ECL plus (GE Healthcare), and the signal was captured using the LAS 3000 system (Fuji Film Co., Tokyo, Japan).

\section{RESULTS}

\section{Interactions between $\beta E_{2}$ and $P R G$}

The beating cilia of the Fallopian tube in guinea pigs at 4 weeks of age are unlikely to be affected by $\beta E_{2}$ and $P R G$, because the ovulation starts at 8 weeks of age in guinea pigs. In the fimbria from 4-week-old guinea pigs, CBF was high $(17.8 \pm$ $0.2 \mathrm{~Hz}, \mathrm{n}=3$ ) (Fig. 1). Our previous report (15) showed that $\mathrm{CBF}$ in the fimbria of 12-16-week-old guinea pigs varies from $12 \mathrm{~Hz}$ to $16 \mathrm{~Hz}$ depending on the phases of the ovarian cycle and that an increase in the plasma concentration of $\beta \mathrm{E}_{2}$ or $\mathrm{PRG}$ decreases CBF. In the present study, $\mathrm{CBF}$ in the fimbriae of 12-16-week-old guinea was highly variable in the absence of exogenous $\beta \mathrm{E}_{2} \mathrm{~B}$ or $\mathrm{mPRG}$ (marked by the " $\downarrow$ " in Fig. 2). Administering both ICI-182,780 $\left(3.2 \mathrm{mg} / \mathrm{kg} /\right.$ day, an inhibitor of $\beta E_{2}$ receptors) and mifepristone $(160 \mathrm{mg} / \mathrm{kg} /$ day, an inhibitor of PRG receptors) increased CBF to its highest value $(17.4 \pm 0.7 \mathrm{~Hz}, \mathrm{n}=3)$ in the fimbriae of 12-week-old guinea pigs (Fig. 1). When we subcutaneously administered both $\beta \mathrm{E}_{2} \mathrm{~B}$ and $\mathrm{mPRG}$ to the guinea pigs, $\mathrm{CBF}$ was high; $17.5 \pm 0.3 \mathrm{~Hz}(\mathrm{n}=3)$

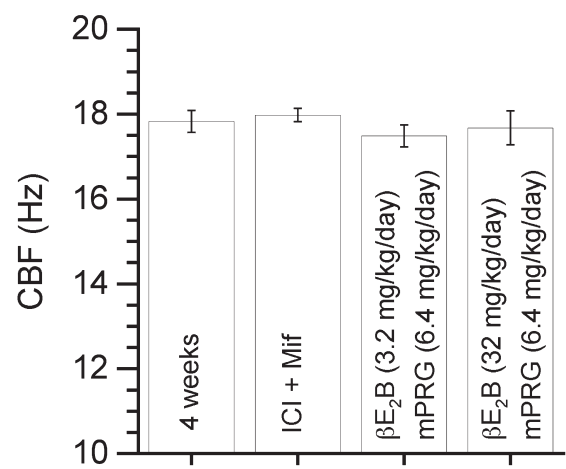

Experiments

Fig. 1 Fimbrial CBFs was measured in slices that were prepared from 4- and 12-16-week-old guinea pigs. CBF was high $(17.8 \mathrm{~Hz})$ in the fimbria of 4-week-old guinea pigs (indicated by "4 weeks"). In 12-16-week-old guinea pigs, the administration of $\mathrm{ICl}-182,780$ (4 mg/kg/day) plus mifepristone $(160 \mathrm{mg} / \mathrm{kg} /$ day) induced high CBF $(18 \mathrm{~Hz})$ (indicated by "ICl + Mif"). However, the administration of $\beta \mathrm{E}_{2} \mathrm{~B}$ at a low dose $(3.2 \mathrm{mg} / \mathrm{kg} /$ day $)$ and $\mathrm{mPRG}$ at a high dose $(6.4 \mathrm{mg} / \mathrm{kg} /$ day) also induced high $C B F(17.5 \mathrm{~Hz})$ (indicated by " $\beta \mathrm{E}_{2} \mathrm{~B}$ (3.2 $\mathrm{mg} / \mathrm{kg} /$ day) + mPRG (6.4 mg/kg/day)"), as did the administration of $\beta E_{2} \mathrm{~B}$ at a high dose $(32 \mathrm{mg} / \mathrm{kg} /$ day $)$ together with $\mathrm{mPRG}$ at a high dose $(6.4 \mathrm{mg} / \mathrm{kg} /$ day) $(17.7 \mathrm{~Hz})$ (indicated by " $\beta \mathrm{E}_{2} \mathrm{~B}$ (32 mg/kg/day) + mPRG (6.4 mg/kg/day)"). 

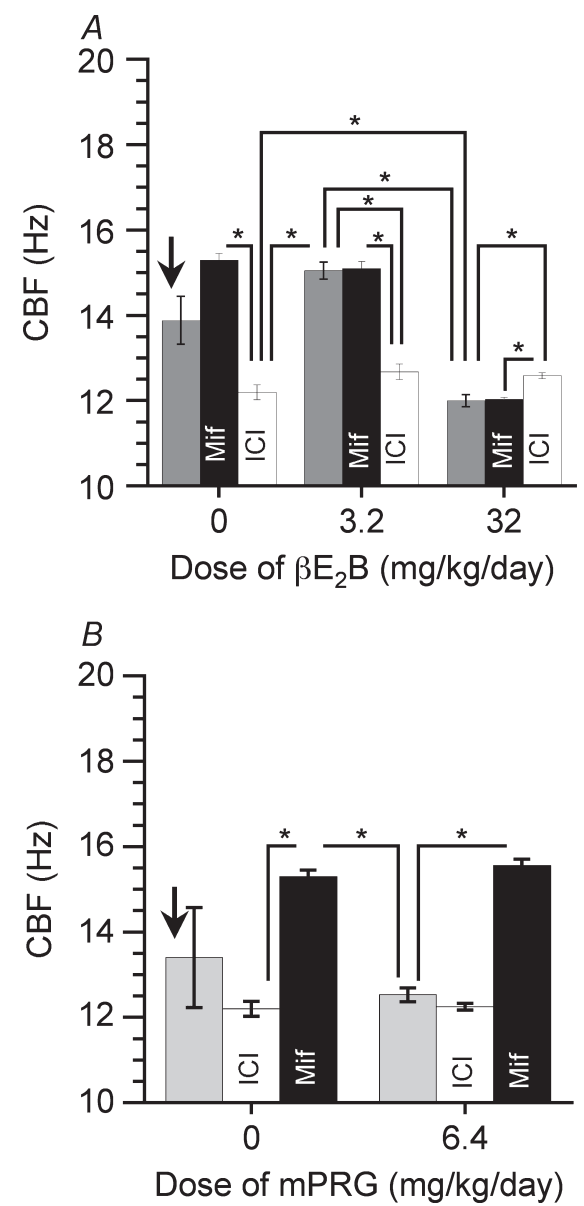

Fig. 2 The effects of $\beta E_{2} B$ and $m P R G$ on CBF in the fimbria. The indicated drugs were subcutaneously injected at the indicated dosages three times over 1.5 days. The guinea pigs were used at 12-16 weeks of age. A: Without any drug injected, CBF varied widely, indicating that endogenously secreted ovarian steroids influence CBF. The CBF obtained from each animal was significantly different from the others within that group $(P<0.001$ by ANOVA, marked by " $\downarrow$ "). Upon the administration of $\beta \mathrm{E}_{2} \mathrm{~B}$ at a dosage of 3.2 or $32 \mathrm{mg} / \mathrm{kg} /$ day, CBF was 14 or $11.5 \mathrm{~Hz}$, respectively. Mifepristone (Mif, $160 \mathrm{mg} / \mathrm{kg} /$ day) had no effects on $\beta \mathrm{E}_{2} \mathrm{~B}$-induced changes in $\mathrm{CBF}$, although mifepristone alone stabilized CBF at $15 \mathrm{~Hz}$. ICl-182,780 (3.2 mg/kg/day), which alone decreased CBF to $12 \mathrm{~Hz}$, abolished the $\beta \mathrm{E}_{2} \mathrm{~B}$-induced changes in CBF. *significantly different $(P<0.05)$. B: Without any drug injected, CBF varied widely. The " $\downarrow$ " shows that the CBF in the fimbriae of three animals were significantly different $(P<0.001$ by ANOVA). Upon the administration of a high dose of mPRG $(6.4 \mathrm{mg} / \mathrm{kg} /$ day $)$, CBF decreased to $12.5 \mathrm{~Hz}$. ICl-182,780 had no effects on mPRG-induced changes in CBF. Mifepristone alone stabilized CBF at $15 \mathrm{~Hz}$ and abolished the mPRG-induced changes in CBF. *significantly different $(P<0.05)$.

with a low dose of $\beta \mathrm{E}_{2} \mathrm{~B}(3.2 \mathrm{mg} / \mathrm{kg} /$ day $)$ plus a high dose of $\mathrm{mPRG}(6.4 \mathrm{mg} / \mathrm{kg} / \mathrm{day})$ and $17.7 \pm$ $0.1 \mathrm{~Hz}(\mathrm{n}=3)$ with a high dose of $\beta \mathrm{E}_{2} \mathrm{~B}(32 \mathrm{mg} / \mathrm{kg} /$ day) plus a high dose of mPRG (6.4 mg/kg/day). A possible explanation for the highest $\mathrm{CBF}$ with both sex steroids is that mPRG inhibits the actions of $\beta \mathrm{E}_{2} \mathrm{~B}$ similarly to ICI-182,780 and $\beta \mathrm{E}_{2} \mathrm{~B}$ inhibits the actions of mPRG similarly to mifepristone (Fig. 1).

\section{Effects of $\beta E_{2} B$}

We examined the effects of $\beta \mathrm{E}_{2} \mathrm{~B}$ on $\mathrm{CBF}$ in the fimbria. No administration of $\beta \mathrm{E}_{2} \mathrm{~B}$ resulted in highly variable $\mathrm{CBF}$; the $\mathrm{CBF}$ that was obtained from each guinea pig was significantly different from the others within that group $(P<0.001$ by ANOVA, marked by the " $\downarrow$ " in Fig. 2), suggesting that CBF is controlled by the endogenously secreted $\beta \mathrm{E}_{2}$ or PRG (15) (Fig. 2A). When guinea pigs were treated with $\beta \mathrm{E}_{2} \mathrm{~B}$ at doses lower than $0.32 \mathrm{mg} / \mathrm{kg} / \mathrm{day}$, highly variable $\mathrm{CBF}$ values were obtained in the fimbriae (data not shown), suggesting that $\beta \mathrm{E}_{2} \mathrm{~B}$ at these doses has no effect on $\mathrm{CBF}$, and that $\mathrm{CBF}$ is controlled by the endogenously secreted $\beta E_{2}$, but not by the injected $\beta \mathrm{E}_{2} \mathrm{~B}(15)$. However, $\beta \mathrm{E}_{2} \mathrm{~B}$ at a dose higher than $3.2 \mathrm{mg} / \mathrm{kg} /$ day caused a more consistent $\mathrm{CBF}$ $(P>0.63$ by ANOVA). Thus, $\mathrm{CBF}$ was $14.8 \pm 0.4 \mathrm{~Hz}$ with low-dose $\beta \mathrm{E}_{2} \mathrm{~B}(3.2 \mathrm{mg} / \mathrm{kg} /$ day $)(\mathrm{n}=3)$ and was $11.7 \pm 0.3 \mathrm{~Hz}(\mathrm{n}=3)$ with high-dose $\beta \mathrm{E}_{2} \mathrm{~B}(32 \mathrm{mg} /$ $\mathrm{kg}$ /day). We used mifepristone $(160 \mathrm{mg} / \mathrm{kg} /$ day $)$ to exclude the effects of endogenous PRG, because $\beta \mathrm{E}_{2} \mathrm{~B}$-induced changes in CBF may be affected by endogenously secreted PRG. Mifepristone had no effect on the $\beta \mathrm{E}_{2} \mathrm{~B}$-induced changes in $\mathrm{CBF}$, although mifepristone alone stabilized $\mathrm{CBF}$ at $15.3 \pm$ $0.2 \mathrm{~Hz}(\mathrm{n}=3)$ (Fig. 2A). Thus, endogenously secreted PRG is unlikely to affect CBF during the administration of a high dose of $\beta \mathrm{E}_{2} \mathrm{~B}$. In the presence of mifepristone alone, the $\mathrm{CBF}$ appears to be stabilized by endogenously secreted $\beta \mathrm{E}_{2}$.

We next examined the effects of ICI-182,780 $\left(3.2 \mathrm{mg} / \mathrm{kg} /\right.$ day) on $\beta \mathrm{E}_{2} \mathrm{~B}$-induced changes in $\mathrm{CBF}$ (Fig. 2A). The administration of ICI-182,780 alone decreased $\mathrm{CBF}$ (to $12.0 \pm 0.3 \mathrm{~Hz}, \mathrm{n}=3$ ) and abolished $\beta \mathrm{E}_{2} \mathrm{~B}$-induced changes in $\mathrm{CBF}$. $\mathrm{CBF}$ was $12.6 \pm 0.5 \mathrm{~Hz}(\mathrm{n}=4)$ at $3.2 \mathrm{mg} / \mathrm{kg} / \mathrm{day}$ and $12.6 \pm$ $0.1 \mathrm{~Hz}(\mathrm{n}=3)$ at $32 \mathrm{mg} / \mathrm{kg} /$ day. In the presence of ICI-182,780 alone, CBF appears to be stabilized by endogenously secreted PRG (see Fig. 2B).

\section{Effects of $m P R G$}

Without administering $\mathrm{mPRG}, \mathrm{CBF}$ was highly variable $(P<0.001$ by ANOVA, marked the " $\downarrow$ " in Fig. 2B). When guinea pigs were treated with $\mathrm{mPRG}$ at doses lower than $0.32 \mathrm{mg} / \mathrm{kg} / \mathrm{day}, \mathrm{CBF}$ remained highly variable $(P<0.001$ by ANOVA), suggesting that mPRG at these doses has no effect on CBF 
(15). However, treatment with $\mathrm{mPRG}$ at doses higher than $6.4 \mathrm{mg} / \mathrm{kg}$ /day resulted in a much less variable CBF $(12.5 \pm 0.2 \mathrm{~Hz}, \mathrm{n}=3)$. The $\mathrm{CBF}$ values that were measured from three guinea pigs were not significantly different ( $P>0.17$ by ANOVA) (Fig. 2B). We used ICI-182,780 $(3.2 \mathrm{mg} / \mathrm{kg} /$ day $)$ to exclude the effects of endogenous $\beta E_{2}$, because endogenous $\beta E_{2}$ may affect $\mathrm{CBF}$ during the administration of $\mathrm{mPRG}$. ICI-182,780 had no effect on the mPRG-induced decrease in CBF, although ICI-182,780 itself decreased $\mathrm{CBF}$ (to $12.0 \pm 0.3 \mathrm{~Hz}, \mathrm{n}=3$ ). Thus, endogenously secreted $\beta \mathrm{E}_{2}$ is unlikely to affect $\mathrm{CBF}$ during the administration of a high dose of $\mathrm{mPRG}$.

We also examined the effects of mifepristone $(160 \mathrm{mg} / \mathrm{kg} /$ day $)$ on the $\mathrm{mPRG}$-induced decrease in $\mathrm{CBF}$. Mifepristone alone stabilized $\mathrm{CBF}$ at $15.3 \pm$ $0.2 \mathrm{~Hz}(\mathrm{n}=3)$ and abolished the decrease in CBF that was induced by $6.4 \mathrm{mg} / \mathrm{kg} /$ day $\mathrm{mPRG}(15.3 \pm$ $0.2 \mathrm{~Hz}, \mathrm{n}=3$ ) (Fig. 2B).

Effects of pretreatment with $\beta E_{2} B$ or $m P R G$ on the $\beta E_{2} B$-plus-mPRG-induced highest $C B F$

The high CBF that was induced by the administration of $\beta \mathrm{E}_{2} \mathrm{~B}$ plus $\mathrm{mPRG}$ suggests that the $\beta \mathrm{E}_{2}$ signaling and the PRG signaling antagonize each other. To confirm the antagonistic actions of $\beta \mathrm{E}_{2} \mathrm{~B}$ and $\mathrm{mPRG}$ in regulating $\mathrm{CBF}$, we subcutaneously injected $\beta \mathrm{E}_{2} \mathrm{~B}$ plus $\mathrm{mPRG}$ into 12 -week-old guinea pigs that were pretreated with either $\beta \mathrm{E}_{2} \mathrm{~B}$ or $\mathrm{mPRG}$ at $3.2 \mathrm{mg} / \mathrm{kg} /$ day or $6.4 \mathrm{mg} / \mathrm{kg} /$ day, respectively (Fig. 3).

In the first experiment, we subcutaneously injected $\mathrm{mPRG}$ to the guinea pigs three times over 1.5 days. This in vivo pretreatment with $\mathrm{mPRG}$ decreased $\mathrm{CBF}$ to $12.8 \pm 0.2 \mathrm{~Hz}(\mathrm{n}=3)$ and prevented the increase in $\mathrm{CBF}$ induced by $\beta \mathrm{E}_{2} \mathrm{~B}$ plus PRG; after the administration of $\beta \mathrm{E}_{2} \mathrm{~B}$ plus mPRG, $\mathrm{CBF}$ was $13.5 \pm 0.1$ (Fig. $3 \mathrm{~A}$ ). In the second experiments, we subcutaneously injected $\beta \mathrm{E}_{2} \mathrm{~B}$ to the guinea pigs three times over 1.5 days. This pretreatment with $\beta \mathrm{E}_{2} \mathrm{~B}$ decreased $\mathrm{CBF}$ to $14.6 \pm 0.2 \mathrm{~Hz}(\mathrm{n}=3)$ and prevented the increase in $\mathrm{CBF}$ induced by $\mathrm{mPRG}$ plus $\beta \mathrm{E}_{2} \mathrm{~B}$; after the administration of $\beta \mathrm{E}_{2} \mathrm{~B}$ plus mPRG, CBF was $14.6 \pm 0.1(n=3)$ (Fig. 3B). Thus, the actions of $\beta \mathrm{E}_{2} \mathrm{~B}$ and $\mathrm{mPRG}$ antagonize each other in regulating $\mathrm{CBF}$.

\section{Plasma $\beta E_{2}$ and $P R G$ concentrations}

The plasma concentrations of $\beta \mathrm{E}_{2}$ and $\mathrm{PRG}$ were measured using EIA kits (Table 1). In 4-week-old guinea pigs, the concentrations of both hormones were low. The subcutaneous injection of $\beta \mathrm{E}_{2} \mathrm{~B}$ resulted in an extremely high plasma $\beta \mathrm{E}_{2}$ concentration. Similarly, subcutaneously injecting $\mathrm{mPRG}$
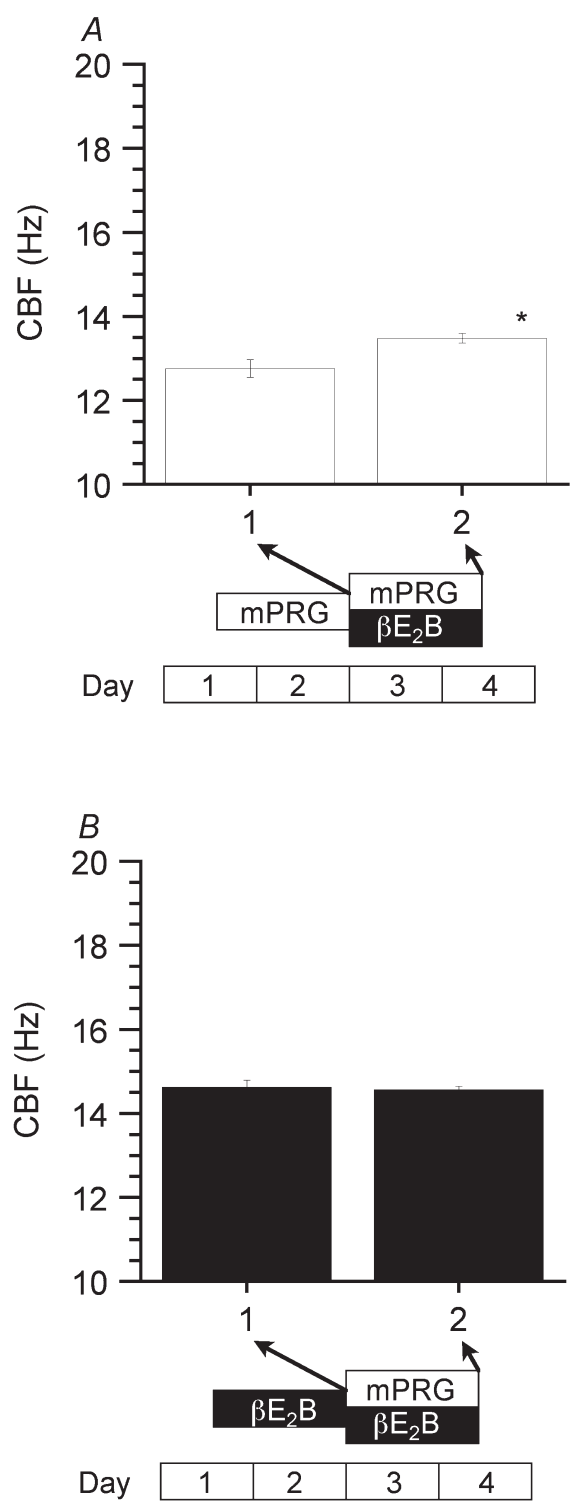

Fig. 3 The effects of $\beta E_{2} B$ plus mPRG on CBF of the fimbria in guinea pigs that were pretreated with $\beta E_{2} B$ or $\mathrm{mPRG}$. Guinea pigs were treated with $\mathrm{mPRG}(6.4 \mathrm{mg} / \mathrm{kg} /$ day) or $\beta E_{2} B(3.2 \mathrm{mg} / \mathrm{kg} /$ day) three times over 1.5 days, prior to the administration of $\beta \mathrm{E}_{2} \mathrm{~B}(3.2 \mathrm{mg} / \mathrm{kg} /$ day) plus $\mathrm{mPRG}$ $(6.4 \mathrm{mg} / \mathrm{kg} /$ day). A: Pretreatment with $\mathrm{mPRG}$ decreased $\mathrm{CBF}$ to $12.8 \pm 0.2 \mathrm{~Hz}(\mathrm{n}=3)$, and the addition of $\beta \mathrm{E}_{2} \mathrm{~B}$ plus mPRG increased CBF only slightly $(13.5 \pm 0.1, n=3, P<$ $0.05)$. However, CBF did not increase to its maximum. $B$ : Pretreatment with $\beta E_{2} B$ decreased $C B F$ to $14.5 \mathrm{~Hz}(n=3)$, and the further addition of $\beta \mathrm{E}_{2} \mathrm{~B}$ plus $\mathrm{mPRG}$ did not induce any increase in CBF. *significantly different $(P<0.05)$.

increased the plasma PRG concentration. ICI-182,780 increased the concentration of $\beta \mathrm{E}_{2}$ and mifepristone increased the concentration of $\mathrm{PRG}$, suggesting that a feedback mechanism increase $\beta \mathrm{E}_{2}$ or PRG secretion. 
Table 1 Plasma $\beta E_{2}$ and PRG concentrations

\begin{tabular}{lcrrrr}
\hline \multicolumn{1}{c}{ Experiment } & \multicolumn{2}{c}{$\beta \mathrm{E}_{2}(\mathrm{pg} / \mathrm{mL})$} & $\mathrm{n}$ & $\mathrm{PRG}(\mathrm{ng} / \mathrm{mL})$ & $\mathrm{n}$ \\
\hline 4 weeks of age & $25.1 \pm$ & 5.1 & 4 & $1.70 \pm 0.3$ & 4 \\
$\beta \mathrm{E}_{2} \mathrm{~B}(\mathrm{~kg} /$ day $)$ & & & & & \\
$3.2 \mathrm{mg}$ & $23170 \pm 2760$ & 3 & $1.70 \pm 0.40$ & 3 \\
$32 \mathrm{mg}$ & $254000 \pm 43700$ & 3 & $3.81 \pm 0.53$ & 3 \\
$\mathrm{mPRG}(6.4 \mathrm{mg} / \mathrm{kg} /$ day $)$ & $34.1 \pm$ & 1.5 & 3 & $18.99 \pm 0.75$ & 3 \\
$\mathrm{ICI}-182,780(3.2 \mathrm{mg} / \mathrm{kg} /$ day $)$ & $71.4 \pm$ & 8.5 & 3 & $2.65 \pm 0.34$ & 3 \\
Mifepristone $(80 \mathrm{mg} / \mathrm{kg} /$ day $)$ & $75.7 \pm$ & 11.8 & 3 & $6.11 \pm 2.18$ & 3 \\
ICI-182,780 +Mifepristone & $43.4 \pm$ & 9.4 & 3 & $4.15 \pm 0.34$ & 3 \\
\hline
\end{tabular}

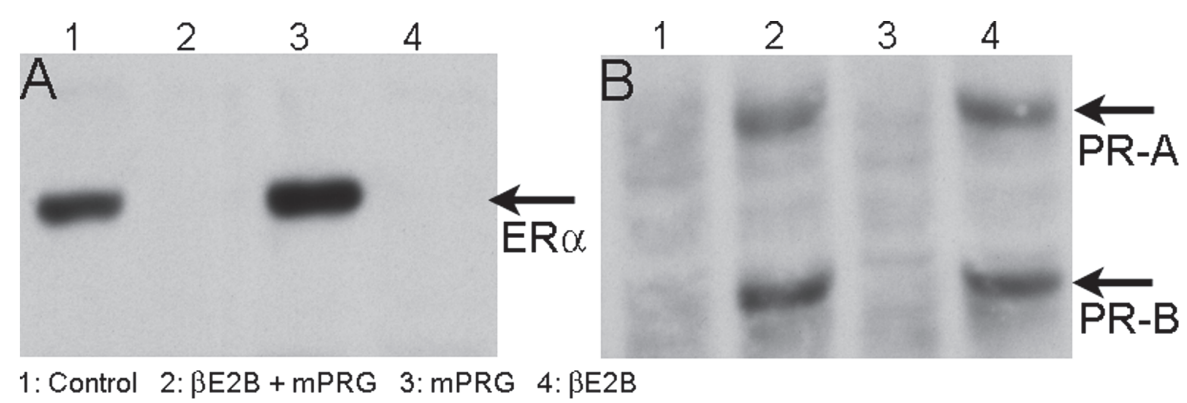

Fig. 4 Western blot analysis of receptors for oestrogen $(\mathbf{A})$ and progesterone (B). Lane 1: control, Lane 2: $\beta E_{2} B$ plus mPRG, Lane 3: mPRG, Lane 4: $\beta \mathrm{E}_{2} \mathrm{~B}$. The anti-PR antibody recognizes both PR-A and PR-B. The administration of $\beta E_{2} B$ plus $\mathrm{mPRG}$ induced the expression of $\mathrm{PRs}$, indicating that the $\beta \mathrm{E}_{2} \mathrm{~B}$ plus $\mathrm{mPRG}$-induced highest $\mathrm{CBF}$ is, at least, not caused by a lack of expression of the receptors.

Expression of $\beta E_{2}$ and $P R G$ receptors in the fimbria The expressions of oestrogen receptor $\alpha(\mathrm{ER} \alpha)$ and the progesterone receptor (PR) were examined following an injection of $\beta \mathrm{E}_{2} \mathrm{~B}$ plus $\mathrm{mPRG}$ or $\mathrm{mPRG}$ or $\beta \mathrm{E}_{2} \mathrm{~B}$ alone three times over 1.5 days in the guinea pigs. Because $\beta \mathrm{E}_{2} \mathrm{~B}$ and $\mathrm{mPRG}$ may induce no expression of the counter hormone receptors. In the absence of exogenous $\beta \mathrm{E}_{2} \mathrm{~B}$ or $\mathrm{mPRG}$, ER $\alpha$ levels were high (Fig. 4A, lane 1), and PR levels were extremely low (Fig. 4A, lane 1). The administration of $\beta \mathrm{E}_{2} \mathrm{~B}$ plus $\mathrm{mPRG}$ induced the expression of $\mathrm{PR}$ but not ER $\alpha$ (lane 2). The administration of $\mathrm{mPRG}$ induced the expression of ER $\alpha$, but not PR (lane 3). Conversely, the administration of $\beta \mathrm{E}_{2} \mathrm{~B}$ induced the expression of PR but not ER $\alpha$ (lane 4). Thus, a high concentration of $\beta E_{2}$ and $P R G$ did not induce the expression of their own receptors via the feedback mechanism, nor did they inhibit the expression of the counter hormone receptors. Upon the administration of $\beta \mathrm{E}_{2} \mathrm{~B}$ plus mPRG, the feedback mechanism via PRG may be suppressed. Although we cannot currently explain the expression of PRs that was induced by $\beta \mathrm{E}_{2} \mathrm{~B}$ plus $\mathrm{mPRG}$, the highest $\mathrm{CBF}$ is not the result of no receptor expression.

\section{DISCUSSION}

In guinea pigs, ovulation begins at 8 weeks of age and occurs cyclically from 12 weeks of age. We found that the concentrations of $\beta \mathrm{E}_{2}$ and $\mathrm{PRG}$ were low in guinea pigs at 4 weeks of age (Table 1). Thus, the fimbriae of guinea pigs at 4 weeks of age are free from the influences of $\beta E_{2}$ and $P R G$ and maintain an extremely high $\mathrm{CBF}(17.8 \mathrm{~Hz})$. Moreover, inhibiting $\beta \mathrm{E}_{2^{-}}$and $\mathrm{PRG}$-receptors increased $\mathrm{CBF}$ to its maximum $(18 \mathrm{~Hz})$ in the fimbria of $12-$ 16 -week-old guinea pigs. Upon the administration of $\beta E_{2} B$ or mPRG, CBF in the fimbria was decreased, which indicates that $\beta \mathrm{E}_{2}$ and $\mathrm{PRG}$ decrease CBF to specific levels (15).

On the other hand, similar to the administration of both inhibitors, the administration of both $\beta \mathrm{E}_{2} \mathrm{~B}$ and $\mathrm{mPRG}$ increased $\mathrm{CBF}$ to its maximum, which suggests that $\beta \mathrm{E}_{2}$ and $\mathrm{PRG}$ antagonize each other in regulating $\mathrm{CBF}$. In this study, we detected no increase in $\mathrm{CBF}$ by the administration of both $\beta \mathrm{E}_{2} \mathrm{~B}$ and $\mathrm{mPRG}$ to guinea pigs that received three pretreatments with mPRG or $\beta \mathrm{E}_{2} \mathrm{~B}$ over 1.5 days. These observations support our hypothesis that $\beta \mathrm{E}_{2}$ and PRG antagonize each other in regulating $\mathrm{CBF}$ in the fimbria. 
Previous reports have shown that $\beta \mathrm{E}_{2}$ and $\mathrm{PRG}$ antagonize each other in certain cellular processes, such as the retraction of long primary dendrites in the female reproductive behavior center of the hypothalamus (6), growth arrest at the G1/S phase of the cell cycle in breast cancer cells $(7,8)$, and neuroprotection in cultured rat hippocampal slices (2). Other studies have also shown their interactive actions of $\beta E_{2}$ and PRG in the morphological differentiation of MCF-7 breast cancer cells (20), and in conferring protection from insulin resistance in diabetic rats (17). In human Fallopian tube explants, $\beta \mathrm{E}_{2}$ prevented the $\mathrm{PRG}$-induced reduction in $\mathrm{CBF}$ (13).

The administration of ICI-182,780 alone stabilized $\mathrm{CBF}$ at a characteristic frequency that was fixed by PRG. During the inhibition of $\beta \mathrm{E}_{2}$ receptors by ICI-182,780, endogenous PRG appears to stimulate its receptor, thus resulting in a decrease in CBF (to $12 \mathrm{~Hz}$ ). Because ICI-182,780 induced a small increase in plasma concentration of PRG, endogenously secreted PRG may stimulate PRs, thereby leading to a decrease in CBF. Conversely, in the presence of mifepristone, endogenously secreted $\beta E_{2}$ may stimulate ERs.

Our western blot analysis revealed that stimulation with $\beta \mathrm{E}_{2} \mathrm{~B}$ or mPRG does not suppress the expressions of the counter hormone receptor. Moreover, the administration of $\beta \mathrm{E}_{2} \mathrm{~B}$ plus mPRG still induced the expression of PRs. Based on these observations, the highest $\mathrm{CBF}$ that was induced by $\beta \mathrm{E}_{2} \mathrm{~B}$ plus $\mathrm{mPRG}$, at least, is not caused by a lack of expression of the receptors. The signal that is stimulated by one hormone receptor may suppress the signal that is stimulated by the other hormone receptor. The addition of both hormones at the same time may suppress both signals, thereby increasing $\mathrm{CBF}$ to its maximum $(17.5 \mathrm{~Hz})$.

In the control experiment, the western blot analysis showed decreased expression of the PRs. However, the guinea pig that was chosen for the control experiment may have been in the luteal phase of the ovarian cycle, in which the plasma concentration of PRG is high (15). This high PRG concentration appears to have suppressed the expression of PRs via the feedback mechanism. However, the addition of $\beta \mathrm{E}_{2} \mathrm{~B}$ plus mPRG still induced the expression of PRs, despite a high plasma PRG concentration. The administration of $\beta \mathrm{E}_{2} \mathrm{~B}$ plus $\mathrm{mPRG}$ may inhibit a feedback mechanism via PRG, which in turn would induce the expression of PRs.

High concentrations of $\beta E_{2}$ or PRG did not induce the expression of their respective receptors.
However, as shown in a previous report (15), the fimbrial $\mathrm{CBF}$ in guinea pigs that were treated with $\beta \mathrm{E}_{2} \mathrm{~B}$ or $\mathrm{mPRG}$ for 4 days was similar to the fimbrial CBF in guinea pigs that were treated for 1.5 days. Although the feedback mechanism via ovarian steroids inhibits the expression of their own receptors, the cells may express a small number of the receptors that maintain a characteristic CBF. Further studies are needed to clarify this mechanism.

In summary, $\beta \mathrm{E}_{2}$ antaginizes PRG-mediated signalling, and vice versa, in regulating $\mathrm{CBF}$ in fimbrial ciliary cells. The characteristic $\mathrm{CBF}$ in each phase of the ovarian cycle is determined by either $\beta \mathrm{E}_{2}$ or PRG (15). In the various phases of the ovarian cycle, $\beta \mathrm{E}_{2}$ and $\mathrm{PRG}$ appear to maintain $\mathrm{CBF}$ by suppressing the signal of each other's hormone. For example, in the ovulation phase, $\beta \mathrm{E}_{2}$ maintains $\mathrm{CBF}$ by inhibiting the actions of $\mathrm{PRG}$, and, in the luteal phase, vice versa. Although the physiological significance of this interaction between $\beta E_{2}$ and $P R G$ is currently unknown, it may play an important role in maintaining CBF and promoting the health of the female reproductive systems $(1,10-12,23)$.

\section{Acknowledgements}

This work was partly supported by a Grants-in Aid for Scientific Research from the Japan Society of the Promotion of Science to T. Nakahari (2159023).

\section{REFERENCES}

1. Afzelius BA (2004) Cilia-related diseases. J Pathol 204, 470-477.

2. Aguirre CC and Baudry M (2009) Progesterone reverses $17 \beta$-estradiol-mediated neuroprotection and BDNF induction in cultured hippocampal slices. Eur J Neurosci 29, 447-454.

3. Amso NN, Crow J, Lewin J and Shaw RW (1994) A comparative morphological and ultrastructural study of endometrial gland and Fallopian tube epithelia at different stages of the mentrual cycle and menopause. Hum Reprod 9, 22342241.

4. Critoph FN and Dennis KJ (1977) Ciliary activity in the human oviduct. Br J Obstet Gynaecol 84, 216-218.

5. Delmotte P and Sanderson MJ (2006) Ciliary beat frequency is maintained at a maximal rate in the small airways of mouse lung slices. Am J Respir Cell Mol Biol 35, 110-117.

6. Griffin GD and Flanagan-Cato LM (2008) Estradiol and progesterone differentially regulate the dendritic arbor of neurons in the hypothalamic ventromedial nucleus of the female rat (Rattus norvegius). J Comp Neurol 510, 631-640.

7. Groshong SD, Owen GI, Grimison B, Schauer IE, Todd MC, Langan TA, Sclafani RA, Lange CA and Horwitz KB (1997) Biphasic regulation of breast cancer cell growth by progesterone: role of the cyclin-dependent kinase inhibitors, p21 and p27(Kip1). Mol Endocrinol 11, 1593-1607.

8. Kandouz M, Lombet A, Perrot JY, Jacob D, Carvajal S, Kazem A, Rostene W, Therwath A and Gompel A (1999) 
Proapoptotic effects of antiestrogens, progestins and androgen in breast cancer cells. J Steroid Biochem Mol Biol 69, 463-471.

9. Livingstone C and Collison M (2002) Sex steroids and insulin resistance. Clin Sci (London) 102, 151-166.

10. Lyons RA, Djahanbakhch O, Mahnood T, Saridogan E, Sattar S, Sheaff MT, Naftalin AA and Chenoy R (2002) Fallopian tube ciliary beat frequency in relation to the stage of menstrual cycle and anatomical site. Hum Reprod 17, 584-588.

11. Lyons RA, Saridogan E and Djahanbakhch O (2006) The reproductive significance of human Fallopian tube cilia. Hum Reprod Update 12, 363-372.

12. Lyons RA, Saridogan E and Djahanbakhch O (2006) The effect of ovarian follicular fluid and peritoneal fluid on Fallopian tube ciliary beat frequency. Hum Reprod 21, 52-56.

13. Mahmood T, Saridogan E, Smutna S, Habib AM and Djahanbakhch O (1998) The effect of ovarian steroids on epithelial ciliary beat frequency in the human Fallopian tube. Hum Reprod 13, 2991-2994.

14. Matsubara E, Nakahari T, Yoshida H, Kuroiwa T, Harada K, Inoue K and Koizumi A (2007) Effects of perfluorooctane sulfonate on tracheal ciliary beating frequency in mice. Toxicology 236, 190-198.

15. Nishimura A, Sakuma K, Shimamoto C, Kuwabara H, Ito S, Nakano T, Ohmichi M, Ushiroyama T, Ueki M, Mori H and Nakahari T (2010) Ciliary beat frequency controlled by oestradiol and progesterone during the ovarian cycle in guineapig Fallopian tube. Exp Physiol 95, 819-828.

16. Nutu $M$, Weijdegård $B$, Thomas $P$, Bergh $C$, Thurin-Kjellberg A, Pang Y, Billig H and Larsson DGJ (2007) Membrane progesterone receptor gamma: Tissue distribution and expression in ciliated cells in the Fallopian tube. Mol Reprod Dev 74, 843-850.

17. Ordóñez $\mathrm{P}$, Moreno $\mathrm{M}$, Alonso A, Llaneza P, Díaz $\mathrm{F}$ and González C (2008) 17 $\beta$-Estradiol and/or progesterone protect from insulin resistance in STZ-induced diabetic rats. $J$ Steroid Biochem Mol Biol 111, 287-294.

18. Pollow K, Inthraphuvasak J, Manz B, Grill HJ and Pollow B (1981) A comparison of cytoplasmic and nuclear estradiol and progesterone receptors in human Fallopian tube and endometrial tissue. Fertil Steril 36, 615-622.

19. Saitoh Y, Koizumi K, Arita N, Hayakawa T, Mogami H, Matsumoto K and Mori H (1986) Antitumor effect of bromocriptine on estrogen-induced rat prolactinomas: ultrastructural alterations of secretory granules. Anticancer Res 6, 1149-1156.

20. Sukocheva OA, Yang Y and Gierthy JF (2009) Estrogen and progesterone interactive effects in postconfluent MCF-7 cell culture. Steroids 74, 410-418

21. Suzuki $T$, Miyamoto $H$, Nakahari $T$, Inoue I, Suemoto $T$, Jiang B, Hirota Y, Itohara S, Saido TC, Tsumoto T, Sawamoto $\mathrm{K}$, Hensch TK, Delgado-Escueta AV and Yamakawa K (2009) Efhc1 deficiency causes spontaneous myoclonus and increased seizure susceptibility. Hum Mol Genet 18, 1099 1109.

22. Takaki E, Fujimoto M, Nakahari T, Yonemura S, Miyata Y, Hayashida N, Yamamoto K, Vallee RB, Mikuriya T, Sugahara K, Yamashita H, Inouye S and Nakai A (2007) Heat shock transcription factor 1 is required for maintenance of ciliary beating in mice. $J$ Biol Chem 282, 37285-37292.

23. Talbot P, Geiske C and Knoll M (1999) Oocyte pickup by the mammalian oviduct. Mol Biol Cell 10, 5-8.

24. Teilmann SC, Clement CA, Thorup J, Byskov AG and Christensen ST (2006) Expression and localization of the progesterone receptor in mouse and human reproductive organs. $J$ Endocrinol 191, 525-535.

25. Westrom L, Mardh PA, Mecklenburg CV and Hakansson $\mathrm{CH}$ (1977) Studies on ciliated epithelia of human genital tract II. The mucociliary wave pattern of Fallopian tube epithelium. Fertil Steril 28, 955-961. 